\title{
Spectrophotometric determination of carbon dioxide and sulphur dioxide in wines by flow injection
}

\author{
G.T. Atanassov, R.C. Lima, R.B.R. Mesquita, \\ A.O.S.S. Rangel* and I.V. Tóth \\ Escola Superior de Biotecnologia, Universidade Católica Portuguesa, Rua Dr. António Bernardino de Almeida, \\ 4200-072 Porto, Portugal
}

\begin{abstract}
Flow injection analysis (FIA) methods for the spectrophotometric determination of $\mathrm{CO}_{2}$ and $\mathrm{SO}_{2}$ in wines are described. The determination of $\mathrm{CO}_{2}$ is based on the colour change of a low capacity buffer (containing an acid-base indicator) due to the dissolved carbon dioxide. The determination of $\mathrm{SO}_{2}$ is based on the decoloration of malachite green by sulphur dioxide. Two FIA manifolds are presented; one for the determination of $\mathrm{CO}_{2}$ in sparkling wines and another for the simultaneous determination of $\mathrm{CO}_{2}$ and $\mathrm{SO}_{2}$ in table wines. The analytes are isolated inside the manifold from the sample matrix using gas-diffusion units. Regression equations (FIA versus reference methods) showed no statistical difference, at $95 \%$ confidence level, between the two sets of results for both determinations; additionally, for the determination of $\mathrm{CO}_{2}$, recovery values between $93.5 \%$ and $111 \%$ were found. RSD lower than $4.5 \%$ for $\mathrm{SO}_{2}$ and $2.4 \%$ for the $\mathrm{CO}_{2}$ determination were found. The sampling rates achieved were: $30 \mathrm{~h}^{-1}$ for the uniparametric system and $40 \mathrm{~h}^{-1}$ for the biparametric system. The single determination manifold is applicable in the concentration ranges of 0.5 to $4 \mathrm{~g} \mathrm{~L}^{-1}$ of $\mathrm{CO}_{2}$, and the simultaneous determination manifold in the range of 0.25 to $3 \mathrm{~g} \mathrm{~L}^{-1}$ of $\mathrm{CO}_{2}$ and 0.05 to $0.3 \mathrm{~g} \mathrm{~L}^{-1}$ of $\mathrm{SO}_{2}$.
\end{abstract}

Key words. Carbon dioxide - sulphur dioxide - wines - flow injection - spectrophotometry.

\section{Introduction}

Sulphur dioxide is commonly used in wine processing to inhibit chemical and microbial spoilage. The amount of $\mathrm{SO}_{2}$ in the final wine product is strictly controlled by legislation. Carbon dioxide can be present in young wines as a product of the fermentation, can indicate spoilage, and in the case of sparkling wines it is added to the wine in high concentration. Both components are important in developing the organoleptic properties of the wines. Therefore, the levels of carbon dioxide and sulphur dioxide are routinely controlled in wineries.

The analytical methods usually used for these determinations are time consuming, often limited in the application range and sometimes affected by the loss of the analyte during the determination [1].

To automate these determinations, some flow injection methodologies have been proposed [2-11]. These methods involve the acidic conversion of the analytes, present in different forms, to $\mathrm{CO}_{2}$ and $\mathrm{SO}_{2}$, and subsequent in-line separation of the gaseous species from the sample matrix, resorting to a gas-diffusion process. Afterwards, the analytes could be detected in the acceptor stream using either spectrophotometric [2-7], electrochemical [7-9] or a chemiluminescence detection $[10,11]$. Spectrophotometric detection of
$\mathrm{CO}_{2}$ is based on the decolorization of an acid base indicator in low capacity buffer stream. Although the reaction is not specific, the use of the gas diffusion process excludes the possible interference of most sample components, except sulphur dioxide, which also diffuses through the membrane. Spectrophotometric determination of $\mathrm{SO}_{2}$ was based on the colorimetric reaction of $\mathrm{SO}_{2}$ with formaldehyde and p-rosaniline [2,6,12] or p-aminoazobenzene [5], with iodine [7], or with malachite green [4]. Regarding electrochemical detection, potentiometry [7,9] and amperometry [8] were used.

The only flow injection system proposed for the simultaneous determination of $\mathrm{CO}_{2}$ and $\mathrm{SO}_{2}$ in wines was described by Linares et al. [12]. A non-specific potentiometric detection ( $\mathrm{pH}$ measurement affected by both analytes) was combined with a spectrophotometric detection of $\mathrm{SO}_{2}$, and the concentrations were calculated using an empirical model.

In this work the objective was to develop one flow injection system for the spectrophotometric determination of $\mathrm{CO}_{2}$ in Portuguese sparkling wines (Vinhos Verdes), avoiding the interference of sulphur dioxide, and another one capable of determining the two analytes with a single manifold. Spectrophotometric detection was preferred as it is more robust and it is usually available in routine control laboratories. 


\section{Materials and methods}

\section{Reagents and solutions}

Reagents with analytical grade and deionized water were used. A $10.0 \mathrm{~g} \mathrm{~L}^{-1}$ stock solution of carbon dioxide was prepared by dissolving $9.55 \mathrm{~g}$ of $\mathrm{NaHCO}_{3}$ in $500 \mathrm{~mL}$ of previously boiled water. The standard solutions of carbon dioxide in the range of 0.5 to $5 \mathrm{~g} \mathrm{~L}^{-1}$ were prepared by rigorous dilution of the stock solution. The standard solutions for the simultaneous determination were prepared as combinations of $\mathrm{CO}_{2}$ with $\mathrm{SO}_{2}$ in the following compositions: $3 \mathrm{~g} \mathrm{~L}^{-1}$ with $0.05 \mathrm{~g} \mathrm{~L}^{-1}, 2 \mathrm{~g} \mathrm{~L}^{-1}$ with $0.1 \mathrm{~g} \mathrm{~L}^{-1}, 1 \mathrm{~g} \mathrm{~L}^{-1}$ with $0.15 \mathrm{~g} \mathrm{~L}^{-1}$, $0.5 \mathrm{~g} \mathrm{~L}^{-1}$ with $0.2 \mathrm{~g} \mathrm{~L}^{-1}$ and $0.25 \mathrm{~g} \mathrm{~L}^{-1}$ with $0.3 \mathrm{~g} \mathrm{~L}^{-1}$, respectively. The standard solutions also contained $0.325 \mathrm{M}$ of $\mathrm{NaOH}$. The working standard solutions and the $\mathrm{SO}_{2}$ stock solution of $1 \mathrm{~g} \mathrm{~L}^{-1}$ were prepared daily and the concentration of the stock solution of $\mathrm{SO}_{2}$ was determined by iodometric titration. The reagent solutions used in the flow injection system were: $20 \mathrm{mg} \mathrm{L}^{-1}$ malachite green in $6.2510^{-3} \mathrm{M}$ $\mathrm{KH}_{2} \mathrm{PO}_{4} ; 0.094 \mathrm{M} \mathrm{K}_{2} \mathrm{HPO}_{4} ; 0.2 \mathrm{M} \mathrm{H}_{2} \mathrm{SO}_{4} ; 300 \mathrm{mg} \mathrm{L}^{-1}$ of $\mathrm{H}_{2} \mathrm{O}_{2}$ in $0.06 \mathrm{M} \mathrm{H}_{2} \mathrm{SO}_{4}$; $60 \mathrm{mg} \mathrm{L}^{-1}$ of $\mathrm{H}_{2} \mathrm{O}_{2}$ in $0.2 \mathrm{M} \mathrm{H}_{2} \mathrm{SO}_{4}$ and a $28 \mathrm{mg} \mathrm{L}^{-1}$ of bromothymol blue in $0.1 \mathrm{mM}$ carbonate buffer at $\mathrm{pH}=7.8$.

\section{Instrumentation and flow injection procedure}

The flow injection systems depicted in figure 1 were composed of Gilson Minipuls 3 peristaltic pumps, a Rheodyne 6 port rotary valve, Unicam $8625 \mathrm{UV} /$ Vis spectrophotometers equipped with Hellma 178011 flow cells and a Kipp \& Zonen BD 112 recorder. The flow channels were constructed using Gilson poly-tetrafluorethilene (PTFE) tubing (i.d. $0.8 \mathrm{~mm}$ ), Omnifit end-fittings and connectors and a Y shaped confluence. Gas diffusion units [13] with straight flow channels $(35 \times 2 \times 0.5 \mathrm{~mm}$ and $70 \times 2 \times 0.5 \mathrm{~mm})$ were used. The applied gas diffusion membranes were made of PTFE and poly-vinylidene fluoride (PVDF) (Millipore, GVHP09050).

\section{Flow injection procedure for the determination of $\mathrm{CO}_{2}$ (Fig. 1A)}

The sample was injected into a water carrier stream $\left(Q_{2}\right)$ and merged with the acid stream $\left(\mathrm{Q}_{3}\right)$ containing hydrogen peroxide. The two streams were mixed in the $\mathrm{R}_{1}$ reactor. When the sample plug reached the gas diffusion unit, part of the free carbon dioxide diffused to the acceptor stream $\left(\mathrm{Q}_{1}\right)$ of carbonate buffer containing the bromothymol blue. Inside the $\mathrm{R}_{2}$ reactor the analyte produced a decrease in the $\mathrm{pH}$ of the buffer stream and the corresponding colour change of the acid base indicator was measured at the flow cell.

\section{Flow injection procedure for the simultaneous determination of $\mathrm{SO}_{2}$ and $\mathrm{CO}_{2}$ (Fig. 1B)}

The sample was injected into a carrier stream of water $\left(\mathrm{Q}_{3}\right)$ and subsequently was mixed with a solution of sulphuric acid $\left(\mathrm{Q}_{4}\right)$ to convert all forms of the analytes to $\mathrm{CO}_{2}$ and $\mathrm{SO}_{2}$. The $\mathrm{SO}_{2}$ that diffused through $\mathrm{GDU}_{1}$ to the acceptor stream $\left(Q_{1}+Q_{2}\right)$ reacted with malachite green and caused the colour change of the solution.

In parallel, the portion of the sample, which remained in the donor channel, was mixed with the solution of $\mathrm{H}_{2} \mathrm{O}_{2}$ to eliminate the remaining $\mathrm{SO}_{2}$, which would interfere in the determination of carbon dioxide. The $\mathrm{CO}_{2}$ then diffused $\left(\mathrm{GDU}_{2}\right)$ to the channel $\mathrm{Q}_{6}$ and caused an alteration of the $\mathrm{pH}$ of the solution and consequently a change in the colour of the acid base indicator.

\section{Sample treatment}

Before introduction in the flow system, the wines were treated with hydroxide to allow the determination of total $\mathrm{SO}_{2}$ and to fix the concentration of $\mathrm{CO}_{2}$. A $20 \mathrm{~mL}$ of $50 \%$ w/w $\mathrm{NaOH}$ was added to bottles containing $750 \mathrm{~mL}$ wine.

\section{Reference determination}

The reference determinations [1] used for evaluating the quality of the results obtained by the FIA methods were: Ripper method for total sulphur dioxide, and a titration of alkalized $\mathrm{CO}_{2}$ with $\mathrm{H}_{2} \mathrm{SO}_{4}$ between $\mathrm{pH} 8.6$ and 4.0 for carbon dioxide.

\section{Results and discussion}

The different parameters of the systems were studied in order to achieve a good sensitivity in the expected determination range. After preliminary experiments to set approximate values for the manifold parameters, an univariate optimization procedure was followed. The values found are presented in figure 1.

\section{$\mathrm{CO}_{2}$ determination}

The manifold was optimized to be able to perform the determination of carbon dioxide in the range of 0.5 to $4 \mathrm{~g} \mathrm{~L}^{-1}$ for sparkling wines.

The injection volume was varied between 50 and $240 \mu \mathrm{L}$. Sensitivity increased with increasing volumes, but the sampling rate decreased due to the longer time necessary to return to the baseline. Therefore, the volume of $100 \mu \mathrm{L}$ was selected for further experiments.

The decrease of the flow rate in the acceptor stream $\left(Q_{1}\right)$ from 3.3 to $1.2 \mathrm{~mL} \mathrm{~min}^{-1}$ produced a higher sensitivity but lowered the sampling rate. Therefore, a compromise value of $1.7 \mathrm{~mL} \mathrm{~min}^{-1}$ flow rate was used.

The length of the reactor $\left(\mathrm{R}_{1}\right)$ was increased up to $50 \mathrm{~cm}$ to allow sufficient mixing. The effect of the length of the $R_{2}$ reactor was studied in the range of 30 to $130 \mathrm{~cm}$. The sensitivity improved up to $120 \mathrm{~cm}$, and decreased for longer ones due to higher dispersion.

Two types of gas diffusion membrane materials, PTFE and PVDF, were tested. When the PTFE membrane was 
A)
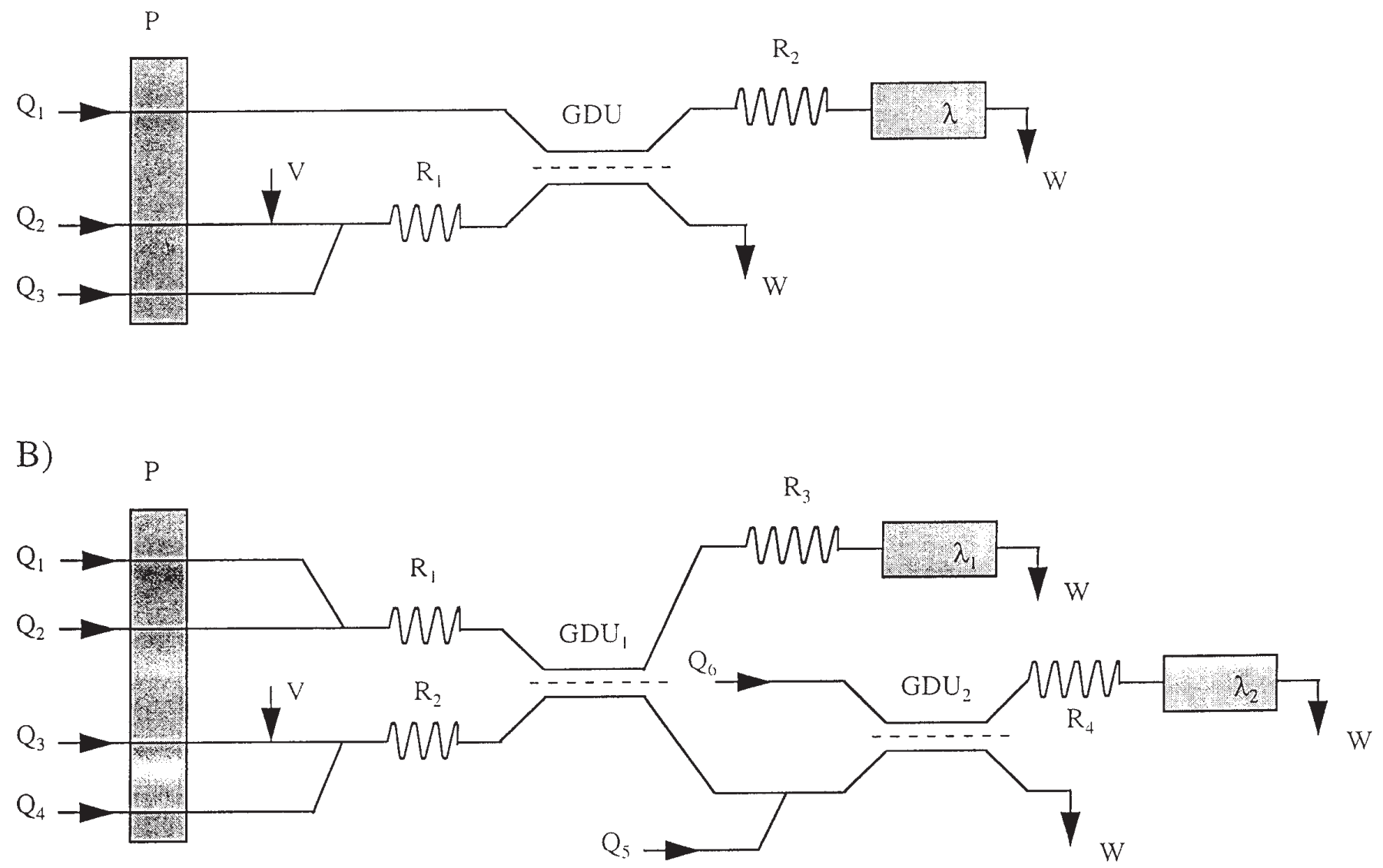

Fig. 1. A. Flow injection manifold developed for the determination of carbon dioxide in wines, P: peristaltic pump; V: injection valve $(100 \mu \mathrm{L}) ; \mathrm{Q}_{\mathrm{i}}$ : reagent streams; $\mathrm{Q}_{1}\left(1.7 \mathrm{~mL} \mathrm{~min}^{-1}\right): 28 \mathrm{mg} \mathrm{L}^{-1}$ bromothymol blue in $0.1 \mathrm{mM}$ carbonate buffer; $\mathrm{Q}_{2}\left(0.8 \mathrm{~mL} \mathrm{~min}{ }^{-1}\right)$ : $\mathrm{H}_{2} \mathrm{O}$; $\mathrm{Q}_{3}\left(1.4 \mathrm{~mL} \mathrm{~min}{ }^{-1}\right) 60 \mathrm{mg} \mathrm{L}^{-1} \mathrm{H}_{2} \mathrm{O}_{2}$ in $0.2 \mathrm{M}$ sulphuric acid solution; $\mathrm{R}_{\mathrm{i}}$ : reactors; $\mathrm{R}_{1}: 50 \mathrm{~cm}$; $\mathrm{R}_{2}: 120 \mathrm{~cm}$; GDU: gas diffusion unit; $\lambda$ : spectrophotometer $(614 \mathrm{~nm})$; W: waste. B. Flow injection manifold developed for the simultaneous determination of $\mathrm{SO}_{2}$ and $\mathrm{CO}_{2}$ in

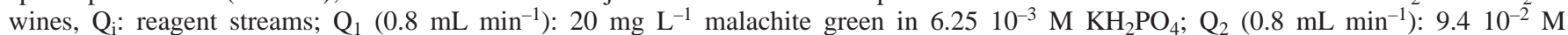
$\mathrm{K}_{2} \mathrm{HPO}_{4} ; \mathrm{Q}_{3}\left(0.8 \mathrm{~mL} \mathrm{~min} \mathrm{~min}^{-1}\right): \mathrm{H}_{2} \mathrm{O} ; \mathrm{Q}_{4}\left(1.3 \mathrm{~mL} \mathrm{~min}{ }^{-1}\right): 0.2 \mathrm{M} \mathrm{H}_{2} \mathrm{SO}_{4} ; \mathrm{Q}_{5}\left(0.3 \mathrm{~mL} \mathrm{~min}{ }^{-1}\right): 300 \mathrm{mg} \mathrm{L} \mathrm{L}_{2}^{-1} \mathrm{H}_{2}$ in $0.06 \mathrm{M} \mathrm{H}_{2} \mathrm{SO}_{4} ; \mathrm{Q}_{6}$ $\left(1.7 \mathrm{~mL} \mathrm{~min}^{-1}\right): 28 \mathrm{mg} \mathrm{L}^{-1}$ bromothymol blue in $0.1 \mathrm{mM}$ carbonate buffer; $\lambda_{\mathrm{i}}$ : spectrophotometers, $\lambda_{1}: 614 \mathrm{~nm}, \lambda_{2}: 617 \mathrm{~nm}$; $\mathrm{R}_{\mathrm{i}}:$ reactors; $\mathrm{R}_{1}, \mathrm{R}_{2}, \mathrm{R}_{4}: 50 \mathrm{~cm} ; \mathrm{R}_{3} 120 \mathrm{~cm}$; other designation are the same as for system in Fig. 1.A.

used the sensitivity at the low concentration range (up to $1.5 \mathrm{~g} \mathrm{~L}^{-1}$ ) was higher than the one achieved with the PVDF membrane. However, the PVDF membrane presented higher resistance to the pressure difference between the two channels; therefore this type of membrane was chosen to guarantee better repeatability.

The sensitivity increased by decreasing the concentration of the carbonate buffer from 0.2 to $0.1 \mathrm{mM}$. The lower concentration was more difficult to handle because of limited stability of the low capacity buffer, due to dissolution of atmospheric carbon dioxide, causing a considerable baseline drift. Therefore, nitrogen was bubbled through the freshly prepared acceptor solution, and subsequently maintained in a closed bottle. This way, no significant sensitivity change was observed for one working day.

By increasing the bromothymol blue concentration in the acceptor stream from 10 to $30 \mathrm{mg} \mathrm{L}^{-1}$ the sensitivity augmented. However, when a $30 \mathrm{mg} \mathrm{L}^{-1}$ concentration was used, the baseline absorbance became too high (>1.8), decreasing dramatically precision. The $28 \mathrm{mg} \mathrm{L}^{-1}$ concentration was used in the subsequent experiments, yielding a stable baseline reading at around 1.5 of absorbance. 


\section{Original articles}

The effect of the acid concentration $\left(\mathrm{Q}_{3}\right)$ on the sensitivity was measured by increasing the concentration of the sulphuric acid in the range of $510^{-3} \mathrm{M}$ to $0.5 \mathrm{M}$. Over $0.2 \mathrm{M}$ the sensitivity in the desired concentration range (up to $5 \mathrm{~g} \mathrm{~L}^{-1}$ ) did not change. Therefore, for the further experiments a $0.2 \mathrm{M}$ solution was used.

The reaction on which the determination is based is about 5 times more sensitive for $\mathrm{SO}_{2}$ than for $\mathrm{CO}_{2}$. Therefore, even in the presence of a small amount of $\mathrm{SO}_{2}$ in the wine, the $\mathrm{CO}_{2}$ result can overestimated. To overcome this problem, hydrogen peroxide was used to oxidise $\mathrm{SO}_{2}$ to $\mathrm{SO}_{4}{ }^{2-}$. As sulphate does not pass through the gas diffusion membrane to the acceptor stream, the interference is avoided. To assess the necessary amount of hydrogen peroxide, its concentration was increased until there was no peak recorded for the injection of $0.3 \mathrm{~g} \mathrm{~L}^{-1} \mathrm{SO}_{2}$ standard solution, as this should be the maximum amount of this analyte in the wine samples [14]. It was found that a $60 \mathrm{mg} \mathrm{L}^{-1}$ concentration of hydrogen peroxide was sufficient for this purpose. As the peaks recorded for the $\mathrm{CO}_{2}$ standards had the same height in the presence or the absence of hydrogen peroxide, it indicated that this amount of hydrogen peroxide had no effect on the $\mathrm{CO}_{2}$ determination.

\section{Simultaneous determination of $\mathrm{SO}_{2}$ and $\mathrm{CO}_{2}$}

Based on the optimized system for $\mathrm{CO}_{2}$, the injection volume, the flow rate and the concentration of the acid stream was kept constant. The part of the system corresponding to the $\mathrm{CO}_{2}$ determination was not changed.

The implemented method for the determination of $\mathrm{SO}_{2}$ was based on the one described by Sullivan et al. [4] and modified to achieve the desired working concentration range (between 0.05 and $0.3 \mathrm{~g} \mathrm{~L}^{-1} \mathrm{SO}_{2}$ ).

The effect of the concentration of the malachite green was studied between 2 and $24 \mathrm{mg} \mathrm{L}^{-1}$. The sensitivity increased with the concentration of the reagent; however, the intense colour of the solution did not allow using higher concentrations. The $20 \mathrm{mg} \mathrm{L}^{-1}$ solution provided a stable baseline reading at around 1.5 of absorbance.

The effect of the acceptor stream flow rate $\left(Q_{1}+Q_{2}\right.$, $\mathrm{Q}_{1}=\mathrm{Q}_{2}$ ) was studied in the range of 1.0 to $2.6 \mathrm{~mL} \mathrm{~min}^{-1}$, sensitivity increased with lower flow rates therefore, $1.2 \mathrm{~mL} \mathrm{~min}^{-1}$ was chosen as a compromise value.

The configuration of the gas diffusion unit was selected to provide a good sensitivity. The sensitivity increased with the length of the flow channel; meanwhile when the zigzag configuration was used, the calibration curve became more affected by the other $\left(\mathrm{CO}_{2}\right)$ component diffusing through the membrane.

The length of the reactor $R_{3}$ was tested in the range of 30 to $200 \mathrm{~cm}$. Since no significant change in sensitivity occurred between 50 and $150 \mathrm{~cm}$, a $50 \mathrm{~cm}$ length, which produced higher sampling rate, was chosen.

\section{Application to wine analysis}

Under the selected conditions, the performance of the flow injection methods was tested, and some of the important characteristics of the systems are presented in table I.

\section{Determination of $\mathrm{CO}_{2}$ in wine}

The proposed method (A) was applied to the determination of $\mathrm{CO}_{2}$ in 13 samples of carbonated Portuguese wines, and the values (in $\mathrm{g} \mathrm{L}^{-1}$ ) were compared with those obtained by the reference method, involving titration of alkalized $\mathrm{CO}_{2}$ with $\mathrm{H}_{2} \mathrm{SO}_{4}$ between $\mathrm{pH} 8.6$ and 4.0. A linear relationship $\left(\mathrm{C}_{\mathrm{FIA}}=\mathrm{C} 0+\mathrm{S} \times \mathrm{C}_{\text {Reference }}\right)$ was established, and the values for intercept $\left(\mathrm{C}_{0}\right)$, slope $(\mathrm{S})$ and the correlation coefficient were $0.018( \pm 0.230), 0.990( \pm 0.086)$ and 0.9916 respectively, where the values in parenthesis are the limits of the $95 \%$ confidence intervals [15]. These figures demonstrate a good agreement between the two methods.

Recovery studies were also carried out to assess the accuracy of the developed method in a wider application range. Three wine samples whose carbon dioxide concentration corresponded to three different ranges of the analysed samples were used. The $\mathrm{CO}_{2}$ was added to the wines in the form of $\mathrm{NaHCO}_{3}$ corresponding to three different levels of $\mathrm{CO}_{2}$ concentration: $0.5,1.0$ and $1.5 \mathrm{~g} \mathrm{~L}^{-1}$. The results obtained are presented in table II. When statistical test ( $t$ test) was used the results showed that the added and the recovered amounts were not different at $95 \%$ significance level; the calculated $t$ value was 1.368 corresponding to a critical $t$ value of 2.306 .

Table I. Some figures of merit of the developed systems.

\begin{tabular}{lccc}
\hline & $\mathrm{CO}_{2}$ system & $\mathrm{CO}_{2}$ & $\mathrm{CO}_{2} / \mathrm{SO}_{2}$ system \\
\hline Repeatability & & $\mathrm{SO}_{2}$ \\
& $1.91\left(0.61 \mathrm{~g} \mathrm{~L}^{-1}\right)$ & $1.5\left(0.81 \mathrm{~g} \mathrm{~L}^{-1}\right)$ & $4.5\left(0.079 \mathrm{~g} \mathrm{~L}^{-1}\right)$ \\
& $0.82\left(2.33 \mathrm{~g} \mathrm{~L}^{-1}\right)$ & $2.4\left(1.4 \mathrm{~g} \mathrm{~L}^{-1}\right)$ & $3.9\left(0.084 \mathrm{~g} \mathrm{~L}^{-1}\right)$ \\
Determination range $\left(\mathrm{g} \mathrm{L}^{-1}\right)$ & $1.06\left(2.74 \mathrm{~g} \mathrm{~L}^{-1}\right)$ & $0.25-3.0$ & $0.05-0.3$ \\
Sampling rate $\left(\mathrm{h}^{-1}\right)$ & $0.5-4.0$ & 40 & \\
\hline
\end{tabular}

a) Calculated from 10 consecutive injections of wine samples. Values in parentheses are the mean concentrations. 
Table II. Recoveries obtained when $0.5,1.0$ and $1.5 \mathrm{~g} / \mathrm{L}$ of $\mathrm{CO}_{2}$ was added to three different wines.

\begin{tabular}{|c|c|c|c|}
\hline No addition, $\mathrm{g} \mathrm{L}^{-1}$ & $1^{\text {st }}$ add. a) & $\begin{array}{l}\text { Recovery, \% } \\
2^{\text {nd }} \text { add. b) }\end{array}$ & $3^{\text {rd }}$ add. c) \\
\hline 0.61 & 100 & 98.0 & 98.8 \\
\hline 2.27 & 98.0 & 102 & 103 \\
\hline 2.74 & 96.0 & 96.7 & 94.7 \\
\hline
\end{tabular}

Addition of a) $0.5 \mathrm{~g} \mathrm{~L}^{-1}$, b) $1.0 \mathrm{~g} \mathrm{~L}^{-1}$ and c) $1.5 \mathrm{~g} \mathrm{~L}^{-1} \mathrm{CO}_{2}$ in the form of sodium carbonate.

\section{Simultaneous determination of $\mathrm{CO}_{2}$ and $\mathrm{SO}_{2}$ in wine}

The developed method (B) was applied for the determination of $\mathrm{CO}_{2}$ and $\mathrm{SO}_{2}$ in Portuguese wines. The results of the $\mathrm{SO}_{2}$ determination were compared with the results obtained by the Ripper method, while the result of the $\mathrm{CO}_{2}$ determination were evaluated by a two level recovery study. The results obtained for the analysis of $\mathrm{SO}_{2}$ in six red and white wines are summarized in table III. The comparison of the results (in $\mathrm{mg} \mathrm{L}^{-1}$ ) obtained for the determination of $\mathrm{SO}_{2}$ with the developed FIA method $\left(\mathrm{C}_{\mathrm{FIA}}\right)$ and with the reference method $\left(\mathrm{C}_{\text {Reference }}\right)$ showed a good agreement as can be perceived from the parameters of the regression equation: $\mathrm{C}_{\mathrm{FIA}}=-0.718( \pm 12.3)+1.002( \pm 0.110) \times \mathrm{C}_{\text {Reference }}$, $\mathrm{R}=0.997$. The values in parentheses are the limits of the $95 \%$ confidence intervals. The recoveries obtained for the $\mathrm{CO}_{2}$ determination showed acceptable accuracy as well. A repeatability study is presented on figure 2 .

\section{Conclusions}

The developed method for the determination of $\mathrm{CO}_{2}$ and $\mathrm{SO}_{2}$ can be quite useful for wine companies, as its allows to monitor both components with the same manifold. No sample pre-treatment is required, which is an advantage over a previous work [12]. It should also be enphasized the possibility of monitoring spectrophotometrically $\mathrm{CO}_{2}$ in the

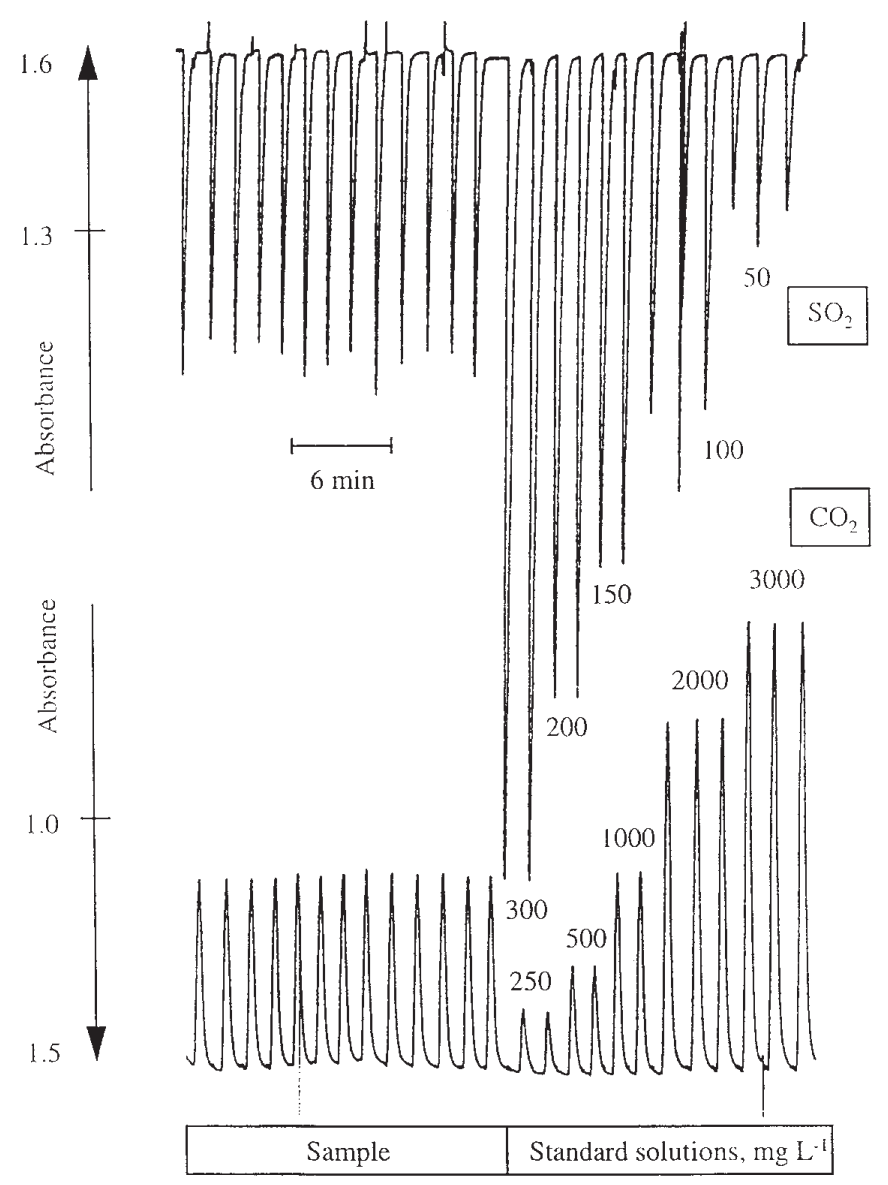

Fig. 2. Recorder output of the simultaneous determination of $\mathrm{CO}_{2}$ and $\mathrm{SO}_{2}$, corresponding to the injection of a set of standards and a sample injected 13 times.

presence of $\mathrm{SO}_{2}$, just by adding hydrogen peroxide to the samples inside the flow system.

Table III. Simultaneous determination of $\mathrm{CO}_{2}$ and $\mathrm{SO}_{2}$ levels in wines by the developed manifold.

\begin{tabular}{|c|c|c|c|c|c|}
\hline $\begin{array}{l}\text { No addition } \\
\mathrm{mg} \mathrm{L}^{-1}\end{array}$ & $\begin{array}{c}\mathrm{CO}_{2} \\
1^{\text {st }} \text { add. }{ }^{\text {a) }}\end{array}$ & $\begin{array}{l}\text { Recovery } \% \\
\\
\qquad 2^{\text {nd }} \text { add. b) }\end{array}$ & $\begin{array}{c}\text { FIA } \\
\mathrm{mg} \mathrm{L}^{-1}\end{array}$ & $\begin{array}{c}\mathrm{SO}_{2} \\
\text { Ripper meth. } \\
\text { mg L L }\end{array}$ & $\mathrm{RD} \%{ }^{\mathrm{c})}$ \\
\hline $\begin{array}{l}432^{\mathrm{d})} \\
820^{\mathrm{d})} \\
475^{\mathrm{d})} \\
288^{\mathrm{e})} \\
801^{\mathrm{e})}\end{array}$ & $\begin{array}{c}96.6 \\
108 \\
102 \\
101 \\
110\end{array}$ & $\begin{array}{c}93.5 \\
97.4 \\
99.6 \\
99.8 \\
111\end{array}$ & $\begin{array}{c}111 \\
102 \\
87.4 \\
94.6 \\
64.6 \\
176^{\mathrm{e}}\end{array}$ & $\begin{array}{c}112 \\
108 \\
84.8 \\
93.6 \\
65.3 \\
175\end{array}$ & $\begin{array}{c}-0.89 \\
-5.5 \\
3.1 \\
1.1 \\
-1.1 \\
0.06\end{array}$ \\
\hline
\end{tabular}

a) Addition of $500 \mathrm{mg} \mathrm{L}^{-1}$, b) addition of $1000 \mathrm{mg} \mathrm{L}^{-1} \mathrm{CO}_{2}$ in the form of carbonate; c) relative deviation; ${ }^{\text {d) }}$ White table wines; ${ }^{\text {e) }}$ Red table wines 


\section{Original articles}

\section{Acknowledgements}

I.V. Tóth thanks the grant PRAXIS XXI/BD/5643/95. G. T. Atanassov thanks TEMPUS SJEP 09841-95 programme. Collaboration of the Sociedade dos Vinhos Borges, S.A. is also acknowledged.

\section{References}

1. Amerine, M. A.; Ough, C. S. Methods for Analysis of Must and Wines; New York: John Wiley, 1980, pp 200-212, pp 278282.

2. Falcone, F.; Maxwel, K. C. J. Agric. Food Chem. 1992, 40, $1355-1357$.

3. Tecator. Determination of total carbonate in beverages (refreshing drinks, sparkling wines, etc.) by flow injection analysis. Application note, ASN 66-21, 1983.

4. Sullivan, J. J.; Hollingworth, T. A.; Wekell, M. M.; Newton, R. T.; Larose, J. E. J. Assoc. Off. Anal. Chem. 1986, 69, 542546.

5. Bartroli, J.; Escalada M., Jorquera, C. J.; Alonso, J. Anal. Chem. 1991, 63, 2532-2535.
6. Mataix E., Luque de Castro M. D. Analyst, 1998, 126, 15471549.

7. Shi, R.; Stein, K.; Schwedt, G. Deutsche Lebensmittel Rundschau 1996, 10, 323-328.

8. Granados, M.; Maspoch, S.; Blanco, M. Anal. Chim. Acta 1986, 179, 445-451.

9. Araújo, A. N.; Couto, C. M. C. M.; Lima, J. L. F. C.; Montenegro M. C. B. S. M. J. Agric. Food Chem. 1998, 46, 168-172.

10. Burguera, J. L.; Burguera, M. Anal. Chim. Acta 1988, 214, 429-432.

11. Huang, Y. L.; Kim, J. M.; Schmid, R. D. Anal. Chim. Acta 1992, 266, 317-323.

12. Linares, P.; Luque de Castro, M. D.; Valcárcel, M. Anal. Chim. Acta 1989, 225, 443-448.

13. Van der Linden, W. E. Anal. Chim. Acta 1983, 51, 359-369.

14. Office International de la Vigne et du Vin (OIV) Recueil des Méthodes Internationales d'Analyse des Vins et des Moûts; OIV: Paris, 1990.

15. Miller, J. C.; Miller, J. N. Statistics for Analytical Chemistry Ellis Horwood: New York, 1993, 3rd ed., pp 120-124. 